\title{
Intangible assets and business results of large companies
}

\author{
Tatiana Cuervo Carabel ${ }^{1}\left[\right.$ iD, Alicia Blanco González² (iD), Carlos del Castillo Peces² ${ }^{2}$ \\ ${ }^{1}$ Universidad Internacional de la Rioja (Spain) \\ ${ }^{2}$ Universidad Rey Juan Carlos (Spain) \\ tatiana.cuervo@unir.net, alicia.blanco@urjc.es, carlos.delcastillo@urjc.es
}

Received November, 2018

Accepted May, 2021

\section{Abstract}

Purpose: To analyze the main types of intangible assets as sources of economic and social outcomes in large corporations.

Design/methodology: We create a sample of large corporations with data from two secondary databases: Fortune Most Admired Companies and Interbrand. We study business' legitimacy through their presence on Google.com. We perform quantitative analysis by testing the proposed hypotheses against a structural equation model built using the PLS method.

Findings: We confirm the value of brands and legitimacy as sources of economic outcomes. We observe that perceived quality and brand equity influence social results. We conclude that perceived quality alone does not improve brand or market value.

Research limitations/implications: The main limitation is related to the characteristics of the companies in the sample: large, highly institutionalized multinational corporations.

Practical implications: The results offer several considerations for managers seeking to improve organizational outcomes. Intangible assets must be managed along with tangible assets in order for organizations to survive and thrive in the marketplace.

Originality/value: The principal contribution of this study is to demonstrate the importance of managing intangible assets so that the organization can maintain or improve its legitimacy and its economic outcomes.

Keywords: Intangible asset, Legitimacy, Brand equity, Perceived quality, Market value, PLS

Jel Codes: M14

\section{To cite this article:}

Cuervo Carabel, T., Blanco González, A., \& del Castillo Peces, C. (2021). Intangible assets and business results of large companies. Intangible Capital, 17(2), 108-123. https://doi.org/10.3926/ic.1390 


\section{Introduction}

The study and analysis of intangible assets has aroused great interest over the years, in the search for business strategies that allow the sustainability of the company in an increasingly competitive market (França \& Rua, 2018; Miotto, Del-Castillo-Feito \& Blanco-González, 2020). Throughout the literature there is a reference to three intangible assets considered key to the success and survival of organizations: perceived quality (Cho \& Pucik, 2005), brand equity (Ludvík, Michal \& Petr, 2018), and legitimacy (Nagy, Rutherford, Truong \& Pollack, 2017; Suddaby, Bitektine \& Haack, 2017; Blanco-González, Diez-Martín, Cachón-Rodríguez \& Prado-Román, 2020).

Perceived quality has been defined in many ways, although one of the most widespread definitions is the one provided by Zeithaml: "consumer judgment of a product as superior or excellent" (1988, p.3). Regarding the brand equity, for Aaker (1991), formed by the assets and liabilities linked to said brand (to its name and symbol), increasing or decreasing the value of a product or service. According to Keller (1993), brand equity is the differentiation caused by the knowledge of the name of a brand on the response of consumers towards it. Lastly, regarding legitimacy, one of the definitions that has had the most impact over the years is the one provided by Suchman: "generalized perception or assumption that the activities of an entity are desirable, correct or appropriate within a system socially constructed of norms, values, beliefs and definitions"(1995, p. 574). It should be noted that, in addition to being an intangible asset, legitimacy has also been analyzed as a social result (Czinkota, Kaufmann \& Basile, 2014). This study analyzes legitimacy as a social result derived from the intangible assets (perceived quality and brand equity) and how, as an intangible asset, per se, generates market value for organizations.

The literature that analyzes the management of intangible assets - perceived quality, brand equity and legitimacy as a guarantee of sustainability for companies is scarce and the results found are diverse. That is why this study seeks to highlight the importance of their management when looking for strategies that allow organizations to maintain and grow in the market.

For this purpose, the following objectives are proposed: first, to analyze the perceived quality, brand equity, and legitimacy, as generators of economic benefits, measured as market value; knowing the relationship between these three intangible assets with the economic results of the company is essential so that their management is incorporated into the business strategy. Second, to study the influence of perceived quality and brand equity on social results, measured as legitimacy, which will allow going deeper into the knowledge of the background of legitimacy for companies, and therefore propose strategies that allow their improvement. Finally, look for the relationship between perceived quality and brand equity, a connection previously studied, but for which there are no clear conclusions in the literature.

It seeks to cover the existing gap identified in the literature, broadening the ability of intangible assets to become a source of competitive advantage, not only independently, but jointly, something that is essential to establish an integrated management strategy in the company.

The study begins with a review of the existing literature that allows the establishment of a series of hypotheses to analyze the relationship between the intangible assets studied and the economic and social benefits of the companies, as well as the relationship between the intangible assets themselves. The sample and methodology used are described below, and the results are presented and discussed. Finally, the conclusions and main managerial implications are established.

\section{Theoretical framework}

\subsection{Intangible assets as creators of economic benefits}

\subsubsection{Perceived quality and market value}

The importance of perceived quality as a source of value for companies has been widely studied. There are many works that relate quality to financial measures such as ROI, return on shares or market, and productivity, 
profitability and survival (McGuire, Schneeweis \& Branch, 1990; Bloom \& Van Reenen, 2007). However, not all authors conclude that the relationship between quality and financial performance is significant. According to Adam et al. (1997), the quality improvement approach has a weak impact on financial performance. Furthermore, for Cho and Pucik (2005), quality alone is not enough to create high performance.

Although, intuitively, it may seem that quality has a positive impact on the performance of the company, including its growth, profitability and market value, the search for strategies that increase such quality can involve difficult decisions in the allocation of resources. Therefore, it is essential for companies to know the factors that can affect their business results in order to manage them properly; allocating the necessary resources to achieve their objectives (Cho \& Pucik, 2005). As established by Agarwal et al. "Good management increases the value of the organization: well-managed companies have higher profitability, are capable of developing superior operational performance for a longer time and are better valued in the market" (2011, p.22).

Given that throughout the literature it is not clear what the relationship is between perceived quality and financial performance, and taking into account the importance indicated by Agarwal, Taffler and Brown (2011) on the management of organizations, it is considered important to determine if perceived quality is among those intangible assets that provide a competitive advantage, since through their creation and exploitation, companies will be able to promote markets, instead of being driven by them (Schwaiger, 2004) if the perception of the quality of a company is constituted, as pointed out by McGuire et al. (1990), as an important variable to explain or predict the financial performance of organizations. Therefore, the following hypothesis is proposed:

\section{Hypothesis H1: Perceived quality directly and positively influences the market value of organizations.}

\subsubsection{Brand equity and market value}

Brand equity is considered one of the most important intangible assets that exists when it comes to business management (Romero \& Yagüe, 2016), as it is positively related to the financial performance of organizations and their survival in the market. "Brands are one of the most valuable assets and their management a key activity in any company" (Ludvík et al., 2018, p. 224). There are several authors who, over the years, have sought the relationship between the dimensions of brand equity and different variables of financial performance such as the price of shares and accounting performance (Verbeeten \& Vijn, 2010); the return of the shares (Mizik \& Jacobson, 2008); or the profit margin (Stahl, Heitmann, Lehmann \& Neslin, 2012). Keller (2001) points out that brand equity has a positive impact on long-term business performance, due to the fact that products and services with high levels of brand equity obtain greater loyalty from consumers, greater resistance in periods of crisis, higher profit margins, greater response to price changes, and licensing and brand extension opportunities, among others.

In this sense, Aaker (2012) points out two points as basis of competition. On one hand, winning the battle "my brand is better than your brand" and, on the other hand, possibly even more important than the first, to achieve brand relevance. Today most products and services do not have differences between them, so the brand generates a significant difference in the market (Zamanimoghadam, Hamdi \& Sediqi, 2014). Brand experience is a key factor in determining why consumers choose a certain brand and not another (Diallo \& Siqueira, 2017), thus improving the financial performance of organizations. For their part, Keller and Brexendorf (2019) point out that brand equity can generate benefits for the company in terms of higher income and / or lower costs.

According to Lo (2012), it is accepted that brand equity has a significant contribution to increasing profitability and value for investors, which is directly related to the success of the organization.

Following this order of ideas, the following hypothesis is proposed:

Hypothesis H2: Brand equity directly and positively influences market value. 


\subsubsection{Legitimacy and market value}

Finally, if legitimacy is thought of as a source of economic benefits for organizations, it is not clear, throughout the literature, whether it is legitimacy that increases the financial performance of organizations, or, on the contrary, if financial performance increases the legitimacy; or if there are more variables that affect said relationship. In fact, over the last few years the number of publications on legitimacy have increased exponentially and the concept has been studied from multiple perspectives (Díez-Martín, Blanco-González \& Prado-Román, 2020), which highlights the crucial role it plays for the companies.

What seems clear is that legitimacy is essential to new companies seeking to gain a foothold in the market (Fisher, Kotha \& Lahiri, 2016; Fisher, Kuratko, Bloodgood \& Hornsby, 2017; Taeuscher, Bouncken \& Pesch, 2021), as well as for those already settled in it (Scott, 2014; Debenedetti, Philippe, Chaney \& Humphreys, 2021), being an intangible asset essential for the survival and success of companies (Del-Castillo-Feito, BlancoGonzález \& Delgado-Alemany, 2020).

The relationship between legitimacy and financial performance has been analyzed in different ways, obtaining disparate results. For authors such as Deephouse and Carter (2005) there is no clear relationship, while authors such as Díez-Martín, Blanco-González, Cruz-Suárez and Prado-Román (2014) conclude a direct and positive relationship between legitimacy and business results, measured through market value.

To analyze the relationship between the two assets, one thinks of the organization's stakeholders, who are a source of legitimacy for it. It is logical to affirm that, if an organization complies with the "established rules" in the eyes of its interested parties, the perception that they will have of it will improve, thus increasing their support for the organization, and improving its performance. That is why the third hypothesis is raised:

Hypothesis H3: Legitimacy influences directly and positively market value.

\subsection{Intangible assets as creators of social benefits}

\subsubsection{Perceived quality and legitimacy}

Throughout the literature there are different works that relate quality management practices such as TQM or the implementation of the ISO 9001 Standard and legitimacy (Heras-Saizarbitoria \& Boiral, 2013; Díez-Martín, Prado-Román \& Blanco-González, 2013; Nagy \& Kacmar, 2013). In this work, the existing relationship between perceived quality and legitimacy will be sought, providing a different point of view to the works found in the literature that so far have not paid attention to this relationship, as can be seen in the bibliographic review developed by Díez-Martín et al. (2020). This is based on the key role that stakeholder expectations play when it comes to both perceived quality and legitimacy.

Zeithaml (1988) considers the consumer as a key piece within the concept of perceived quality, which differs from the quality of the product because it is a subjective evaluation of it by the consumer (Erenkol \& Duygun, 2010), in which its expectations will be part of that perception.

Legitimacy has also been associated with society's perceptions towards the organization, being one of the sources of legitimacy identified by the literature (Nagy et al., 2017; Díez-Martín et al., 2020; Martín-de Castro, 2021). For Zimmerman and Zeith (2002), legitimacy is a social judgment of acceptance, convenience and desirability that allows organizations to access other resources necessary to survive and grow. In fact, Suchman (1995) points out that one of the ways to increase organizational legitimacy is by adopting socially accepted techniques, which include meeting stakeholder expectations.

Following this order of ideas, it is logical to think that if the perceived quality is increased, meeting the expectations of the clients, as part of the society that they are, will also increase legitimacy. Therefore, the

following hypothesis is proposed:

Hypothesis H4: Perceived quality directly and positively influences legitimacy. 


\subsubsection{Brand equity and legitimacy}

Good brand equity management generates legitimacy in organizations, as stated by Czinkota et al. (2014) and Liu et al. (2014).

From a consumer perspective, the power of a brand resides in the minds of consumers and what they have experienced and learned about the brand over time (Keller \& Brexendorf, 2019). The fact that a consumer has learned, felt, seen, and heard positive things about a certain brand, can create in them a judgment of acceptance, convenience, and desirability towards said brand, increasing its legitimacy (Zimmerman \& Zeith, 2002). Therefore, it can be stated that if the brand equity is increased, for example, through marketing or advertising actions (Huang \& Sarigollu, 2014; Makasi, Govender \& Rukweza, 2014; Zamanimoghadam et al., 2014; Gupta, 2015), it influences the perception of consumers and thus legitimacy increases. That is why the following hypothesis is proposed:

\section{Hypothesis H5: Brand equity directly and positively influences legitimacy.}

\subsection{Relationships between intangible assets: perceived quality and brand equity}

Regarding the relationship between perceived quality and brand equity, there are no clear conclusions in the analyzed literature. Most authors consider perceived quality as a precursor of brand equity when treating it as one of its dimensions (Buil, de Chernatony \& Martínez, 2013; Severi \& Ling, 2013; Šerić, Gil-Saura \& Mikulić, 2017), although there are also studies that analyze the brand equity as a precursor of perceived quality (Calvo \& Montes, 2012) and others that do not find a relationship between both variables (Kimpakorn \& Tocquer, 2010; Dib \&Alhaddad, 2014; Subramaniam, Mamun, Permarupan \& Noor, 2014).

When analyzing this relationship taking into account the consumer perspective proposed by Severi and Ling (2013), if a consumer considers a product or a brand as superior or excellent, that is to say, with a high perceived quality, their reaction to said product or brand will be positive. Increasing the perceived quality will increase brand equity. According to Calvo and Montes "a high perceived quality takes place when consumers recognize the differentiation and superiority of a brand in relation to other competing brands. This perceived quality will influence their purchasing decisions and their choice of brand, choosing those in which a higher quality is perceived" (2012, p.7). The following hypothesis is therefore proposed:

Hypothesis H6: Perceived quality directly and positively influences brand equity.

\section{Sample and methodology}

\subsection{Sample}

To develop this study, a sample of companies included in two databases is used: Fortune-World's Most Admired Companies, previously used by other authors such as McGuire et al. (1990) or Cho and Pucik (2005), to measure the perceived quality, having confirmed its validity and reliability; and Interbrand Best Global Brands, taking into account that their evaluations are sufficiently relevant and reliable for their use (Barth, Clement, Foster \& Kasznik, 1998), being also one of the most used bases when analyzing brand equity (Madden, Fehle \& Fournier, 2006), which provides a broad perspective, by involving both, the financial and consumer perspectives (Torres, Bijmolt, Tribó \& Verhoef, 2012). The sampling is not focused on a specific sector, seeking the diversity of it and thus, avoiding sampling biases (Blair \& Zinkhan, 2006), as done by other authors such as Díez-Martín, BlancoGonzález and Prado-Román (2016), and a period of three years (2011, 2012 and 2013) is used as Cho and Pucik (2005), having concluded after the application of the Wilcoxon non-parametric test, that none of the variables: perceived quality, brand equity, market value, and legitimacy, depends on the period under study, so increasing the number of years would not affect the results.

The sample is limited to US companies for three reasons: to use homogeneous, reliable, and accessible indices to measure perceived quality and brand equity; a similar competitive macroeconomic environment; and that they are companies with business models and strategies developed in different sectors (Díez-Martín et al., 2014). 
The sample is made up of the twenty-one companies that appear simultaneously in Fortune-World's Most Admired Companies and Interbrand-Best Global Brands in the analyzed period: Apple, Amazon, Google, CocaCola, Starbucks, General Electric, McDonald's, Microsoft, Nike, JP Morgan Chase, UPS, PepsiCo, eBay, Johnson \& Johnson, Goldman Sachs Group, IBM, 3M, Walt Disney, American Express, Intel, and Caterpillar.

Table 1 shows a summary of the characteristics of the companies, taking into account their size, calculated as the average of total revenues in the three years under study (2011-2013) published on the Fortune 500 website. Only one of the companies would have revenues of less than $\$ 20$ billion, while four of them would earn more than $\$$ 100 billion. The average of the total income of the companies in the sample in the three years of the study, $\$ 1.3$ trillion dollars, constitutes $7.46 \%$ of the total GDP of the United States. According to the data of the World Bank, the period 2010-2014 was $\$ 17.42$ trillion dollars, for which the sample is considered representative.

\begin{tabular}{|l|r|r|}
\hline Firm size by revenue (\$ Millions) & Firms & \% Firms in Sample \\
\hline Less than 20.000 & 1 & $4.76 \%$ \\
\hline $20.000-30.000$ & 2 & $9.52 \%$ \\
\hline $30.000-40.000$ & 4 & $19.05 \%$ \\
\hline $40.000-50.000$ & 2 & $9.52 \%$ \\
\hline $50.000-60.000$ & 4 & $19.05 \%$ \\
\hline $60.000-70.000$ & 4 & $19.05 \%$ \\
\hline More than 100.000 & 4 & $19.05 \%$ \\
\hline Total & $\mathbf{2 1}$ & $\mathbf{1 0 0 \%}$ \\
\hline
\end{tabular}

Table 1. Summary of firms in sample by size

Table 2 summarizes the characteristics of the sample by economic sector. As can be seen in the sample, six economic sectors are represented: technology, consumer services, consumer products, industrial, financial and health care.

\begin{tabular}{|c|r|r|}
\hline Economic Sector & Firms & \% Firms in Sample \\
\hline Technology & 5 & $23.81 \%$ \\
\hline ConsumerServices & 6 & $28.57 \%$ \\
\hline ConsumerProducts & 3 & $14.29 \%$ \\
\hline Industrial & 3 & $14.29 \%$ \\
\hline Financial & 3 & $14.29 \%$ \\
\hline Health care & 1 & $4.75 \%$ \\
\hline Total & $\mathbf{2 1}$ & $\mathbf{1 0 0 \%}$ \\
\hline
\end{tabular}

Table 2. Summary by economic sector

\subsection{Methodology}

To measure perceived quality, one of the criteria from Fortune-World's Most Admired Companies list is used, quality of products / services, taking into account that, as established by different authors, it is one of the most recognized and reliable classifications at an international level (McGuire et al., 1990; Cho \& Pucik, 2005; DíezMartín et al., 2014).

Following Cho and Pucik (2005), as the results of Fortune take one year to be published, the data from the Fortune website used for the quality of products and services criterion was published in March 2012, 2013 and 2014, corresponding to the years 2011, 2012 and 2013. The scale used is from 1 to 10 points, so that 10 means the company in the sector with the worst perceived quality index and 1 the best.

To measure brand equity, Interbrand is used as a data source. Taking into account, as established by Madden et al. (2006), Interbrand is one of the most used databases when analyzing brand equity, being also recognized throughout the world. Following Barth et al. (1998), Interbrand valuations are sufficiently relevant and reliable for their use and there is no evidence of bias between said value and the market value of the companies. 
The market valuewas obtained by calculating the average value of the company's share prices in the year under study. The value of the shares was obtained from Yahoo Finance.

Finally, following what is established by Deephouse, Bundy, Tost and Suchman (2017), who point out that the rapid change associated with the development of information and communication technologies (ICT) has meant that the media, such as the written press, have seen their "authority" affected to influence legitimacy of the organizations. A legitimacy analysis has been carried out through the news published on Google.com instead of using the written press as usual, taking into account that the analysis of large analytical data allows generating new knowledge on variables widely studied in the literature previously from another perspective (Xiang, Schwartz, Gerdes \& Uysal, 2015).

To do this, through Google.com, a search is made of the news generated in the US for the companies in the sample in 2011, 2012 and 2013. The search terms are: company name, year, and news generated in the USA each news item is coded according to its impact on the legitimacy of the company $(0=$ neutral, $1=$ negative, and $2=$ positive). Verification was carried out, by three external researchers, of the coding of a random selection of 60 news items. The three coders agreed in 56 of the 60 cases analyzed (93.33\%), which suggests a high degree of reliability (Weber, 1991). To calculate legitimacy, the Janis-Fadner coefficient is used as did Deephouse (1996).

Table 3 shows the number of news analyzed by company on Google.com.

\begin{tabular}{|l|r|r|r|}
\cline { 2 - 4 } \multicolumn{1}{c|}{} & \multicolumn{3}{c|}{ News analyzed } \\
\hline Company & $\mathbf{2 0 1 1}$ & $\mathbf{2 0 1 2}$ & $\mathbf{2 0 1 3}$ \\
\hline Nikple & 348 & 524 & 488 \\
\hline eBay & 433 & 362 & 335 \\
\hline J.P.Morgan Chase & 234 & 163 & 168 \\
\hline PepsiCo & 328 & 356 & 328 \\
\hline Amazon & 317 & 316 & 280 \\
\hline Starbucks & 441 & 424 & 457 \\
\hline Google & 370 & 350 & 329 \\
\hline Coca-Cola & 526 & 461 & 445 \\
\hline GE & 310 & 269 & 264 \\
\hline McDonald's & 270 & 279 & 271 \\
\hline Microsoft & 223 & 201 & 253 \\
\hline Ups & 456 & 477 & 381 \\
\hline IBM & 96 & 93 & 141 \\
\hline 3M & 346 & 371 & 437 \\
\hline Johnson \& Johnson & 117 & 122 & 130 \\
\hline Walt Disney & 219 & 201 & 247 \\
\hline Caterpillar & 246 & 240 & 247 \\
\hline Intel & 108 & 201 & 229 \\
\hline American Express & 315 & 365 & 449 \\
\hline Goldman Sachs Group & 127 & 151 & 211 \\
\hline
\end{tabular}

Table 3. Number of news analyzed by company on Google.com

Finally, a quantitative analysis is developed, making use of structural modeling with PLS. At this point, it should be mentioned that taking into account the provisions of Díez-Martín et al. (2014) the variations are used in each indicator, var (2012-2011) and var (2013-2012); considering in a differentiated way two periods for the study,2012-2011 and 2013-2012, to carry out a comparative analysis between the sample companies and homogenize the results (not all companies have the same resources). It should also be noted that for the perceived quality index, the variation will change sign, since, as previously commented, 1 implies the best index, while 10 implies the worst, that is, contrary to the other variables, the lower the value, the better perceived quality. 


\section{Results}

Table 4 shows the descriptive analysis of the constructs in the sample.

\begin{tabular}{|c|c|c|c|c|}
\hline \multirow[b]{2}{*}{ Construct } & \multicolumn{2}{|c|}{ 2012-2011 } & \multicolumn{2}{|c|}{ 2013-2012 } \\
\hline & Mean & SD* & Mean & SD* \\
\hline Quality & -0.100 & 1.334 & -0.047 & 1.203 \\
\hline Legitimacy & 0.075 & 0.095 & 0.044 & 0.121 \\
\hline Brand Equity & 4130.762 & 9644.845 & 3416.762 & 6557.576 \\
\hline Market Value & 8.594 & 12.100 & 18.190 & 30.253 \\
\hline
\end{tabular}

*SD: Standard Deviation

Table 4. Descriptive analysis

The first step has been to evaluate the collinearity of the constructs, determining the VIF parameter and taking tolerance levels, established by Hair, Hult, Ringle and Sarstedt (2014). Lower than 0.20 (VIF> 5.00) in the predictor construct, as an indication that there is collinearity that can affect the results, altering the signs. As can be seen in Table 5, there are no collinearity problems, as it does not exceed the established value in any case.

\begin{tabular}{|c|c|c|c|c|c|c|c|c|c|}
\hline & \multicolumn{4}{|c|}{ 2012-2011 } & \multicolumn{4}{|c|}{ 2013-2012 } \\
\hline & & Quality & Legitimacy & Brand & Market & Quality & Legitimacy & Brand & Market \\
\hline \multirow{4}{*}{$\begin{array}{l}2012- \\
2011\end{array}$} & Quality & & 1.000 & 1.000 & 1.148 & & & & \\
\hline & Legitimacy & & & & 1.387 & & & & \\
\hline & Brand & & 1.000 & & 1.247 & & & & \\
\hline & Market & & & & & & & & \\
\hline \multirow{4}{*}{$\begin{array}{l}2013- \\
2012\end{array}$} & Quality & & & & & & 1.002 & 1.000 & 1.127 \\
\hline & Legitimacy & & & & & & & & 1.147 \\
\hline & Brand & & & & & & 1.002 & & 1.030 \\
\hline & Market & & & & & & & & \\
\hline
\end{tabular}

Table 5. Collinearity Results (VIF)

The results obtained using PLS were then analyzed taking into account the considerations listed below. The criterion for determining the significance of the parameters was established through a bootstrap resampling procedure of 5000 subsamples of a size equal to the original sample (Hair et al., 2014). To assess the predictive capacity of the structural model, the criterion proposed by Falk and Miller (1992) was followed, which establishes that the $\mathrm{R} 2$ of each of the dependent constructs must be greater than 0.1 to be accepted.

In addition, the acceptance or rejection of the hypotheses was evaluated taking into account the significance or not of the standardized regression coefficients. Following Hair et al. (2014) it can be stated that the coefficients close to +1 and -1 represent a strong and generally statistically significant relationship in the structural model. On the contrary, values very small, close to zero, are generally not significant. Finally, the T Statistic value was analyzed establishing a significance level of $5 \%$, therefore taking as a critical value to determine the significance of said parameter 1.96 (Hair et al., 2014).

The data collected in Table 6 show that the $\mathrm{R} 2$ of the factor dependent legitimacy $\left(\mathrm{R}^{2}=0.279\right)$ and market value $\left(\mathrm{R}^{2}=0.653\right)$ exceed the critical level mentioned in the 2012-2011 period. The value obtained for the brand equity $\left(\mathrm{R}^{2}=0.000\right)$ is not significant. This makes it possible to evaluate the acceptance or rejection of the hypotheses $\mathrm{H} 1, \mathrm{H} 2, \mathrm{H} 3, \mathrm{H} 4$ and $\mathrm{H} 5$ raised, taking into account the significance or not of the estimated standardized regression coefficients.

The results obtained confirm the positive and significant influence of the brand equity on the market value of the companies $(\beta=0.416 ; \mathrm{T}=2.147$; H2) for the period 2012-2011, so that a higher brand equity helps organizations to improve their market value.

Market value is also influenced by legitimacy in this period for a significance value of $5 \%(\beta=0.514 ; \mathrm{T}=2.443$; $\mathrm{H} 3$ ), thus confirming the importance of legitimacy as an intangible asset for organizations. 
On the other hand, a positive and significant influence of perceived quality on legitimacy is confirmed for a significance value of $10 \%(\beta=0.326 ; \mathrm{T}=1.793 ; \mathrm{H} 4)$. This relationship would show how the perceived quality influences the social results of the company. There is also a relationship between brand equity and legitimacy. Brand equity directly and positively influences legitimacy for a significance value of $5 \%(\beta=0.422 ; \mathrm{T}=2.464$; H5). This result would show the importance of brand equity as an intangible asset, due to its influence on the social results of organizations.

\begin{tabular}{|lcrc|}
\hline \multicolumn{1}{c}{ Hypothesis } & Standardized $\boldsymbol{\beta}$ & T-Value & Evaluation \\
\hline H1: Quality-MarketValue & 0.093 & 0.671 & Rejected \\
\hline H2: Brand Equity-Market Value & 0.416 & $2.147^{* *}$ & Accepted \\
\hline H3: Legitimacy-MarketValue & 0.514 & $2.443^{* *}$ & Accepted \\
\hline H4: Quality-Legitimacy & 0.326 & $1.793^{*}$ & Accepted \\
\hline H5: Brand Equity-Legitimacy & 0.422 & $2.464^{* *}$ & Accepted \\
\hline H6: Quality-Brand Equity & -0.019 & 0.144 & Rejected \\
\hline
\end{tabular}

$\mathrm{R}^{2}$ (Brand) $=0.000 ; \mathrm{R}^{2}$ (Legitimacy) $=0.279 ; \mathrm{R}^{2}$ (Market) $=0.653$

$* \mathrm{p}<0.01 ; * * \mathrm{p}<0.05 ; * * * \mathrm{p}<0.001$

Table 6. Hypothesis evaluation, 2012-2011

The data collected in Table 7 show that the $R^{2}$ of the dependent factors legitimacy $\left(R^{2}=0.128\right)$ and market value $\left(\mathrm{R}^{2}=0.406\right)$ exceed the mentioned critical level (Falk and Miller (1992) criterion, $\mathrm{R}^{2}$ greater than 0.1) also in the period 2013-2012. The value obtained for the brand equity $\left(\mathrm{R}^{2}=0.002\right)$ is not significant for this period either. Once again, the acceptance or rejection of the hypotheses H1, H2, H3, H4 and H5 raised can be evaluated, taking into account the significance or not of the estimated standardized regression coefficients.

The results obtained confirm, also in this case, the positive and significant influence of the brand equity on the market value of the companies $(\beta=0.416$; $T=1.646 ; \mathrm{H} 2)$, for a significance level of 0.01 . A positive and significant influence of legitimacy on the market value is also observed $(\beta=0.401$; $\mathrm{T}=2.227$; $\mathrm{H} 3)$, for a significance level of 0.05 .

The relationship between perceived quality and legitimacy is observed again in this period, for a significance level of $5 \%(\beta=0.330 ; \mathrm{T}=2.028 ; \mathrm{H} 4)$, however in this case the model has not confirmed the Table 7 .

\begin{tabular}{|l|r|r|c|}
\hline \multicolumn{1}{|c|}{ Hypothesis } & Standardized $\beta$ & T-Value & Evaluation \\
\hline H1: Quality-MarketValue & 0.084 & 0.674 & Rejected \\
\hline H2: Brand Equity-Market Value & 0.416 & $1.646^{*}$ & Accepted \\
\hline H3: Legitimacy-MarketValue & 0.401 & $2.227^{* *}$ & Accepted \\
\hline H4: Quality-Legitimacy & 0.330 & $2.028^{* *}$ & Accepted \\
\hline H5: Brand Equity-Legitimacy & 0.156 & 1.004 & Rejected \\
\hline H6: Quality-Brand Equity & -0.048 & 0.490 & Rejected \\
\hline
\end{tabular}

$\mathrm{R}^{2}$ (Brand) $=0.002 ; \mathrm{R}^{2}$ (Legitimacy) $=0.128 ; \mathrm{R}^{2}$ (Market) $=0.406$

${ }^{*} \mathrm{p}<0.01 ; * * \mathrm{p}<0.05 ;{ }^{* * *} \mathrm{p}<0.001$

Table 7. Hypothesis evaluation, 2013-2012

\section{Discussion}

There are three objectives of this study. On one hand, analyze perceived quality, brand equity and legitimacy as sources of competitive advantage that provide economic benefits to companies. On the other hand, study perceived quality and brand equity as generators of social benefits for companies. Finally, delve into the relationship between perceived quality and brand equity. Based on these objectives, the results are discussed.

Hypothesis 1 establishes a direct and positive relationship between perceived quality and market value. The results have not confirmed this relationship. The rejection of this hypothesis may be due to the fact that the market value is not only influenced by the perceived quality, but there are other factors that make it oscillate and that, therefore, do not allow us to observe the relationship between these two variables with clarity. Authors such 
as Adam et al. (1997) and Cho and Pucik (2005) support this fact. According to Adam et al. (1997), when quality improves, there is not only an impact on the performance of the organization, but on many other variables. For Cho and Pucik (2005), quality alone is not enough to create high growth. Furthermore, Rizwan, Usman, Hussain, Shafiq, Rauf and Ayaz (2013) also concluded that the performance of an organization not only improves with perceived quality, but it also does so by developing customer trust and satisfaction. It can be affirmed, therefore, that perceived quality is not the only variable that influences the market value of an organization, as has been evident in this study where it has been reflected that, for example, the value of the brand and legitimacy would also influence it. Perceived quality is a source of competitive advantage that must be managed (Cho \& Pucik, 2005; Agarwal et al., 2011), but it is not the only one. It is clear that the relationship between perceived quality and market value is complex and is influenced by the organization's management of other assets, something that highlights the importance of having a joint vision of intangible assets such as that is presented in this study.

Hypothesis 2 establishes a direct and positive relationship between brand equity and market value. The results have confirmed this relationship in both periods under study, which confirms what was previously concluded by authors such as Lo (2012) or Romero and Yagüe (2016) who also observed this relationship. In addition, in the case of this work, it should be noted that this relationship was verified for a type of companies with particular characteristics, such as multinational companies, without focusing on a specific sector. This has made it possible to expand the existing literature until the moment in which most of the works reviewed focus on specific sectors or companies when analyzing this asset (Buil et al., 2013). In addition, most studies analyze the relationship between brand equity and business performance, through the dimensions of brand equity: loyalty, notoriety, perceived quality, brand associations (Buil et al., 2013). This work, however, analyzed the brand equity in a global way, without breaking it down into those dimensions, thus providing another approach that allows expanding the existing knowledge in relation to this intangible asset.

Hypothesis 3 establishes a direct and positive relationship between legitimacy and market value. The results have confirmed this relationship in both periods under study. Legitimacy becomes another of the fundamental intangible assets when analyzing the behavior of organizations in the market, as has been stated by authors such as Del-Castillo-Feito et al. (2020) who consider it essential for the survival and success of companies. Furthermore, as Fisher et al. (2016) states, legitimacy should be considered not only as a source of resources, but also as a resource for the organization itself. The results of this research allow us to conclude that legitimacy plays a crucial role, not only for newly created companies (Taeuscher et al., 2021), but for multinational companies, which already have their niche and recognition in the market, therefore, is an asset whose management must be present in any organization, taking into account that once the company has legitimacy, its importance becomes evident when it is lost (Scott, 2014).

Hypothesis 4 establishes a direct and positive relationship between perceived quality and legitimacy. The results have confirmed this relationship in both periods under study. Suchman (1995) points out three strategies to manage legitimacy: strategies to gain, strategies to maintain, and strategies to regain lost legitimacy. The results of this study allow us to affirm that the management of perceived quality constitutes a strategy to gain and maintain legitimacy. Therefore, while it is true that it has not been possible to confirm a direct relationship between the perceived quality and the market value of the companies, these results highlight that companies cannot forget about the management of perceived quality. Management strategies must focus on the interested parties and their expectations, taking into account that both the perceived quality and the legitimacy will depend on their perceptions of the company and its products / services (Erenkol \& Duygun, 2010; Díez-Martín, BlancoGonzález \& Díez-de-Castro, 2021; Martín-de Castro, 2021). Once again, it is clear the need not to limit ourselves to studying the different intangible assets individually, but to have a joint vision.

Hypothesis 5 establishes a direct and positive relationship between brand equity and legitimacy. The results have confirmed this relationship for the period 2012-2011, so the hypothesis is partially confirmed. This may be due to the fact that the companies that make up the sample are large multinational companies, with a strong roots in the market and a high degree of institutionalization, so they are completely legitimized, which makes them accepted by society, preventing fluctuations in brand equity from directly affecting social results, and obstructing, 
in some cases, the budgeted relationship between brand equity and legitimacy. In this sense, as established by Liu, Eng and Sekhon (2014), when the brand is identified to achieve legitimacy, it is necessary to align its sociocultural meanings with that of its audiences. Companies can actively work to influence and modify perceptions of the environment (Cruz-Suárez, Díez-Martín, Blanco-González \& Prado-Román, 2014). In this case, the companies in the sample are established in the market and have managed to align the brand they represent with their environment. However, although it is true that the companies in the sample show small variations in brand equity and that these do not affect legitimacy, the results of this work show that these types of companies have to correctly manage their brand to maintain their legitimacy.

Finally, Hypothesis 6 establishes a direct and significant relationship between perceived quality and brand equity. The results of the analysis of the structural model have not allowed validating the relationship between both assets. Perceived quality is confirmed as one of the assets of brand equity, but it will not be the only one. As previously commented, most of the reviewed papers analyze this variable taking into account its dimensions. For example, for Kim and Kim (2005), loyalty, the perception of quality and the image of the brand are the precursors of brand equity. For their part, Buil et al. (2013), point out that in addition to perceived quality, brand equity is also influenced by loyalty, notoriety and brand associations. Finally, Chang and Chen (2013) find perceived quality and brand awareness as the antecedents of brand equity. However, it should not be forgotten that there are several authors who, although they have analyzed brand equity taking into account its dimensions, have not found a relationship between perceived quality and said value. For Kimpakorn and Tocquer (2010), the variables that most influence brand equity are brand differentiation and trust, and not perceived quality. Neither do Dib and Alhaddad (2014) and Subramaniam et al. (2014) find the influence of perceived quality on brand equity. For Dib and Alhaddad (2014), brand equity is influenced by brand awareness, brand trust and loyalty, while for Subramaniam et al. (2014) it is loyalty and brand image that have a positive and significant influence on brand equity. In this study, brand equity is analyzed, without taking its dimensions into account, and, therefore, it cannot be discerned whether the fact of not observing a direct and significant relationship between both assets is associated with the perceived quality itself It alone does not serve to improve brand equity, as there are other dimensions that make up this asset, as some authors point out, or on the contrary, there is no such relationship, as others point out.

\section{Conclusions}

The results of this study show that companies must go beyond the management of tangible assets. Intangible assets have become a strategic resource for organizations, which cannot focus only on their tangible assets if they want to ensure their sustainability.

The first conclusion of this study indicates that both brand equity and legitimacy are two of the main intangible assets that organizations have to guarantee not only their survival, but also their progression and continuous improvement in the market, since they directly influence and positively in the market value of the companies. Both must be included in the overall management of organizations. It can also be stated that, although perceived quality is important, companies cannot focus their efforts on increasing it, since they would risk that this is not enough to ensure their competitiveness. However, the managers of the organizations should consider that this asset is a source of competitive advantage and, therefore, it will have to be managed, without losing sight of the rest of the assets, tangible and intangible, that the organization has.

The second conclusion of this research shows that an inadequate management of perceived quality or brand equity can endanger the sustainability of the company if the organization goes against its already legitimized principles, generating loss of trust and, therefore, so much, of legitimacy, that it can be fatal to the interests of any company. Establishing appropriate marketing and advertising strategies will be critical to managing perceived quality and brand equity, as well as maintaining and enhancing legitimacy, thereby increasing competitiveness in the market.

The first limitation of this study would be associated with the characteristics of the companies that make up the sample. To overcome this limitation, future research could expand the sample, including other types of 
companies, with fewer resources and a lower degree of institutionalization and roots in the market, such as newly created companies. A comparison between both types of companies could be interesting to continue delving into the management of these intangible assets in organizations. A second limitation of the study would be related to the methodology used to measure legitimacy through Google.com, taking into account the paradigm shift caused by the increasing use of social networks in recent years. For this reason, it is proposed as another future line of research the analysis of legitimacy through the presence of companies in social networks such as Twitter or Facebook, and its comparison with the analysis through the press or Google.com, to be able to discern if the results thrown vary and how they do it.

Finally, based on the results obtained, it is considered important to expand this study by analyzing brand equity, taking into account its dimensions, and discerning whether the results are a consequence of the existence of other dimensions that affect brand equity, in addition to the perceived quality, and that they have masked the relationship between both intangible assets, or, on the contrary, there is no relationship, as pointed out by some authors.

\section{Declaration of Conflicting Interests}

The authors declared no potential conflicts of interest with respect to the research, authorship, and/or publication of this article.

\section{Funding}

The authors received no financial support for the research, authorship, and/or publication of this article.

\section{References}

Aaker, D. (1991). Managing brand equity. New York: The Free Press.

Aaker, D.A. (2012). Win the brand relevance battle and then build competitor barriers. California Management Review, 54(2), 43-57. https://doi.org/10.1525/cmr.2012.54.2.43

Adam, E.E., Corbett, L.M., Flores, B.E., Harrison, N.J., Lee, T.S., Rho, B. et al. (1997). An international study of quality improvement approach and firm performance. International Journal of Operations \& Production Management, 17(9), 842-873. https://doi.org/10.1108/01443579710171190

Agarwal, V., Taffler, R., \& Brown, M. (2011). Is management quality value relevant?. Journal of Business Finance \& Accounting, 38(9-10), 1184-1208. https://doi.org/10.1111/j.1468-5957.2011.02267.x

Barth, M.E., Clement, M.B., Foster, G., \& Kasznik, R.(1998). Brand values and capital market valuation. Review of Accounting Studies, 3(1), 41-68. https://doi.org/10.1023/A:1009620132177

Blair, E., \& Zinkhan, G.M. (2006). Nonresponse and generalizability in academic research. Journal of the Academy of Marketing Science, 34(1), 4-7. https://doi.org/10.1177/0092070305283778

Blanco-González, A., Diez-Martín, F., Cachón-Rodríguez, G., \& Prado-Román, C. (2020). Contribution of social responsibility to the work involvement of employees. Corporate Social Responsibility and Environmental Management, 27(6), 2588-2598. https://doi.org/10.1002/csr.1978

Bloom, N., \& Van Reenen, J. (2007). Measuring and explaining management practices across firms and countries. The Quarterly Journal of Economics, 122(4), 1351-1408. https://doi.org/10.1162/qjec.2007.122.4.1351

Buil, I., de Chernatony, L., \& Martínez, E. (2013). La importancia de medir el valor de marca desde la perspectiva del consumidor: Evidencia empírica en España y el Reino Unido. Revista De Ciencias Sociales, 19(2), 226-237. https://doi.org/10.31876/rcs.v19i2.25619

Calvo, C., \& Montes, P. (2012). Mahou y Coronita: Análisis comparado del valor de marca para el consumidor español. Redmarka: Revista Académica De Marketing Aplicado, 2 (9), 3-28.

https://doi.org/10.17979/redma.2012.02.09.4752 
Chang, C., \& Chen, Y. (2013). Managing green brand equity: The perspective of perceived risk theory. Quality \& Quantity, 48(3), 1753-1768. https://doi.org/10.1007/s11135-013-9872-y

Cho, H., \& Pucik, V. (2005). Relationship between innovativeness, quality, growth, profitability, and market value. Strategic Management Journal, 26(6), 555-575. https://doi.org/10.1002/smj.461

Cruz-Suárez, A., Díez-Martín, F., Blanco-González, A., \& Prado-Román, C. (2014). Análisis de las relaciones entre la legitimidad organizativa, sus fuentes y dimensiones. Revista Venezolana De Gerencia, 19(65), 9-22. https://doi.org/10.1002/smj.461

Czinkota, M., Kaufmann, H.R., \& Basile, G.(2014). The relationship between legitimacy, reputation, sustainability and branding for companies and their supply chains. Industrial Marketing Management, 43(1),91-101. https://doi.org/10.1016/j.indmarman.2013.10.005

Debenedetti, A., Philippe, D., Chaney, D., \& Humphreys, A. (2021). Maintaining legitimacy in contested mature markets through discursive strategies: The case of corporate environmentalism in the French automotive industry. Industrial Marketing Management,92, 332-343. https://doi.org/10.1016/j.indmarman.2020.02.009

Deephouse, D.L. (1996). Does isomorphism legitimate?. The Academy of Management Journal, 39(4), 1024-1039. https://doi.org/10.5465/256722

Deephouse, D., \& Carter, S. (2005). An examination of differences between organizational legitimacy and organizational reputation. Journal of Management Studies, 42(2), 329-360. https://doi.org/10.1111/j.14676486.2005.00499.x

Deephouse, D.L., Bundy, J., Tost, L.P., \& Suchman, M.C. (2017). Organizational legitimacy: Six keyquestions. In Greenwood, R., Oliver, C., Lawrence, T., \& Meyer, R. (Eds). The SAGE Handbook of Organizational Institutionalism (2nd ed.) (pp. 27-52). CA: SAGE Publications. https://doi.org/10.4135/9781446280669.n2

Del-Castillo-Feito, C., Blanco-González, A., \& Delgado-Alemany, R. (2020). The relationship between image, legitimacy, and reputation as a sustainable strategy: Students' versus professors' perceptions in the higher education sector. Sustainability,12(3), 1189. https://doi.org/10.3390/su12031189

Diallo, M.F., \& Siqueira Jr, J. R. (2017). How previous positive experiences with store brands affect purchase intention in emerging countries: A comparison between Brazil and Colombia. International Marketing Review, 34(4), 536-558. https://doi.org/10.1108/IMR-07-2014-0224

Dib, H., \& Alhaddad, A. (2014). The hierarchical relationship between brand equity dimensions. European Scientific Journal, 10(28), 183-194.

Díez-Martín, F., Prado-Román, C., \& Blanco-González, A. (2013). Efecto del plazo de ejecución estratégica sobre la obtención de legitimidad organizativa. Investigaciones Europeas De Dirección y Economía De La Empresa, 19(2), 120-125. https://doi.org/10.1016/j.iedee.2013.01.001

Díez-Martín, F., Blanco-González, A., Cruz-Suárez, A., \& Prado-Román, C. (2014). Efecto de la responsabilidad social empresarial sobre la legitimidad de las empresas. Anuario Jurídico y Económico Escurialense, 47, 325-348.

Díez-Martín, F., Blanco-González, A., \& Prado-Román, C. (2016). Explaining nation-wide differences in entrepreneurial activity: A legitimacy perspective. International Entrepreneurship and Management Journal, 12(4), 1-24. https://doi.org/10.1007/s11365-015-0381-4

Díez-Martín, F., Blanco-González, A., \& Prado-Román, C. (2020). The intellectual structure of organizational legitimacy research: a co-citation analysis in business journals. Review of Managerial Science, 15, 1-37. https://doi.org/10.1007/s11846-020-00380-6

Díez-Martín, F., Blanco-González, A., \& Díez-de-Castro, E. (2021). Measuring a scientifically multifaceted concept. The jungle of organizational legitimacy. European Research on Management and Business Economics, 27(1), 100131. https://doi.org/10.1016/j.iedeen.2020.10.001

Erenkol, A.D., \& Duygun, A. (2010). Customers perceived brand equity and a research on the customers of Bellona which is a Turkish furniture brand. The Journal of American Academy of Business,16(1), 93-109. 
Falk, R.F., \& Miller, N.B. (1992). A primer for soft modeling. OH: University of Akron Press.

Fisher, G., Kotha, S., \& Lahiri, A. (2016). Changing with the times: An integrated view of identity, legitimacy, and new venture life cycles. Academy of Management Review, 41(3), 383-409. https://doi.org/10.5465/amr.2013.0496

Fisher, G., Kuratko, D. F., Bloodgood, J. M., \& Hornsby, J. S. (2017). Legitimate to whom? The challenge of audience diversity and new venture legitimacy. Journal of Business Venturing, 32(1), 52-71.

https://doi.org/10.1016/j.jbusvent.2016.10.005

França, A., \& Rua, O.L. (2018). Relationship between intangible resources, absorptive capacities and export performance. Tourism \& Management Studies,14(1), 94-107. https://doi.org/10.18089/tms.2018.14108

Gupta, S. (2015). Enhancing brand equity through sustainability: Waste recycling. Thunderbird International Business Review, 58(3), 213-223. https://doi.org/10.1002/tie.21730

Hair, J.P., Hult, G.T., Ringle, C.M., \& Sarstedt, M. (2014). A primer on partial least squares structural equations modeling (PLS-SEM). CA: SAGE.

Heras-Saizarbitoria, I., \& Boiral, O. (2013). ISO 9001 and ISO 14001: Towards a research agenda on management system standards. International Journal of Management Reviews, 15(1), 47-65. https://doi.org/10.1111/j.1468-2370.2012.00334.x

Huang, R., \& Sarigollu, E. (2014). Assessment of brand equity measures. International Journal of Market Research, 56(6), 783-806. https://doi.org/10.2501/IJMR-2014-037

Interbrand Best Global Brands (2014). http://www.interbrand.com/es/Default.aspx [Accessed: April, 2014].

Keller, K.L. (1993). Conceptualizing, measuring, and managing customer-based brand equity. The Journal of Marketing, 57(1), 1-22. https://doi.org/10.1177/002224299305700101

Keller, K.L. (2001). Building customer-based brand equity: A blueprint for creating strong brands. USA: Marketing Science Institute.

Keller K.L., \& Brexendorf T.O. (2019). Measuring Brand Equity. In Esch FR. (eds), Handbuch Markenführung. Springer Gabler, Wiesbaden: Springer Reference Wirtschaft. https://doi.org/10.1007/978-3-658-13342-9_72

Kim, H-b., \& Kim, W.G. (2005). The relationship between brand equity and firms' performance in luxury hotels and chain restaurants. Tourism Management, 26(4), 549-560. https://doi.org/10.1016/j.tourman.2004.03.010

Kimpakorn, N., \& Tocquer, G. (2010). Service brand equity and employee brand commitment. Journal of Services Marketing, 24(5), 378-388. https://doi.org/10.1108/08876041011060486

Liu, G., Eng, T., \& Sekhon, Y. (2014). Managing branding and legitimacy: A study of charity retail sector. Nonprofit and Voluntary Sector. Quarterly, 43(4), 629-651. https://doi.org/10.1177/0899764012474722

Lo, S.C. (2012). Success in business-A brand equity perspective. American Journal of Applied Sciences, 9(3), 388-391. https://doi.org/10.3844/ajassp.2012.388.391

Ludvík, E., Michal, M. \& Petr, R. (2018). Employer Branding on social media and recruitment websites: Simbolic traits of an ideal employer. E\&M Economics \& Management, 2(1), 224-237.

https://doi.org/10.15240/tul/001/2018-1-015

Madden, T. J., Fehle, F., \& Fournier, S. (2006). Brands matter: An empirical demonstration of the creation of shareholder value through branding. Journal of the Academy of Marketing Science, 34(2), 224-235. https://doi.org/10.1177/0092070305283356

Makasi, A., Govender, K., \& Rukweza, C. (2014). Building brand equity through advertising. Mediterranean Journal of Social Sciences, 5(20), 2613-2624. https://doi.org/10.5901/mjss.2014.v5n20p2613

Martín-de Castro, G. (2021). Exploring the market side of corporate environmentalism: reputation, legitimacy and stakeholders' engagement. Industrial Marketing Management, 92, 289-294.

https://doi.org/10.1016/j.indmarman.2020.05.010 
McGuire, J., Schneeweis, T., \& Branch, B. (1990). Perceptions of firm quality: A cause or result of firm performance. Journal of Management, 16(1), 167-180. https://doi.org/10.1177/014920639001600112

Miotto, G., Del-Castillo-Feito, C., \& Blanco-González, A. (2020). Reputation and legitimacy: Key factors for Higher Education Institutions' sustained competitive advantage. Journal of Business Research, 112, 342-353. https://doi.org/10.1016/j.jbusres.2019.11.076

Mizik, N., \& Jacobson, R. (2008). The financial value impact of perceptual brand attributes. Journal of Marketing Research, 45(1), 15-32. https://doi.org/10.1509/jmkr.45.1.15

Nagy, B.G., \& Kacmar, K.M. (2013). Increasing customer satisfaction in the new venture context. Journal of Research in Marketing and Entrepreneurship, 15(2), 143-159. https://doi.org/10.1108/JRME-11-2012-0029

Nagy, B.G., Rutherford, M.W., Truong, Y., \& Pollack, J.M. (2017). Development of the legitimacy threshold scale. Journal of Small Business Strategy, 27(3), 50-58.

Romero, J., \& Yagüe, M.J. (2016). Marketing assets: Relating brand equity and customer equity. Intangible Capital, 12(2), 591-618. https://doi.org/10.3926/ic.727

Rizwan, M., Usman, A., Hussain, T., Shafiq, A., Rauf, S., \& Ayaz, Q. (2013). The impact of the perceived quality, customer satisfaction, brand trust and contextual factors on brand loyalty. International Journal of Research in Commerce and Management, 4(3), 83-89.

Schwaiger, M. (2004). Components and parameters of corporate reputation: An empirical study. Schmalenbach Business Review, 56(1), 46-71. https://doi.org/10.1007/BF03396685

Scott, W.R. (2014). Institutions and organizations. Ideas, interests and identities (4th ed.). CA: SAGE.

Šerić, M., Gil-Saura, I., \& Mikulić, J. (2017). Customer-based brand equity building: Empirical evidence from Croatian upscale hotels. Journal of Vacation Marketing, 23(2), 133-144. https://doi.org/10.1177/1356766716634151

Severi, E., \& Ling, K.C. (2013). The mediating effects of brand association, brand loyalty, brand image and perceived quality on brand equity. Asian Social Science, 9(3), 125-137. https://doi.org/10.5539/ass.v9n3p125

Stahl, F., Heitmann, M., Lehmann, D.R., \& Neslin, S.A. (2012). The impact of brand equity on customer acquisition, retention, and profit margin. Journal of Marketing, 76(4), 44-63. https://doi.org/10.1509/jm.10.0522

Subramaniam, A., Mamun, A.A., Permarupan, P.Y., \& Noor, R.B.Z. (2014). Effects of brand loyalty, image and quality on brand equity: A study among bank islam consumers in Kelantan, Malaysia. Asian Social Science, 10(14), 67-73. https://doi.org/10.5539/ass.v10n14p67

Suddaby, R., Bitektine, A., \& Haack, P. (2017). Legitimacy. Academy of Management Annals,11(1): 451-478. https://doi.org/10.5465/annals.2015.0101

Suchman, M.C. (1995). Managing legitimacy: Strategic and institutional approaches. The Academy of Management Review, 20(3), 571-610. https://doi.org/10.5465/amr.1995.9508080331

Taeuscher, K., Bouncken, R.B., \& Pesch, R. (2021). Gaining legitimacy by being different: Optimal distinctiveness in crowdfunding platforms. Academy of Management Journal, 64(1), 149-179.

https://doi.org/10.5465/amj.2018.0620

Torres, A., Bijmolt, T.H.A., Tribó, J.A., \& Verhoef, P. (2012). Generating global brand equity through corporate social responsibility to key stakeholders. International Journal of Research in Marketing, 29(1), 13-24.

https://doi.org/10.1016/j.ijresmar.2011.10.002

Verbeeten, F.H.M., \& Vijn, P. (2010). Are brand-equity measures associated with business-unit financial performance? Empirical evidence from the Netherlands. Journal of Accounting, Auditing and Finance, 25(4), 645-671. https://doi.org/10.1177/0148558X1002500408

Weber, R.P. (1991). Basic content analysis (2nd ed.). CA: SAGE. https://doi.org/10.4135/9781412983488 
Xiang, Z., Schwartz, Z., Gerdes, J. H., \& Uysal, M. (2015). What can big data and text analytics tell us about hotel guest experience and satisfaction?. International Journal of Hospitality Management, 44, 120-130.

https://doi.org/10.1016/j.ijhm.2014.10.013

Zamanimoghadam, A., Hamdi, K., \& Sediqi, M. (2014). Investigating different factors influencing on brand equity. Management Science Letters, 4(7), 1391-1396. https://doi.org/10.5267/j.msl.2014.6.031

Zeithaml, V.A. (1988). Consumer perceptions of price, quality, and value: A means. Journal of Marketing, 52(3), 2. https://doi.org/10.1177/002224298805200302

Zimmerman, M., \& Zeitz, G. (2002). Beyond survival: Achieving new venture growth by building legitimacy. The Academy of Management Review, 27(3), 414-431. https://doi.org/10.5465/amr.2002.7389921

Intangible Capital, 2021 (www.intangiblecapital.org)

\section{(c) (1) \$}

Article's contents are provided on an Attribution-Non Commercial 4.0 Creative commons International License. Readers are allowed to copy, distribute and communicate article's contents, provided the author's and Intangible Capital's names are included. It must not be used for commercial purposes. To see the complete license contents, please visit https://creativecommons.org/licenses/by-nc/4.0/. 